This work was supported by grants from the Wellcome Trust, the North of England Council of the British Empire Cancer Campaign, and the Scientific and Research Subcommittee of the Royal Victoria Infirmary. The advice of Professor G. A. Smart, Professor A. L. Latner, and Dr. F. Clark and the technical assistance of Mrs. A. Hewison are gratefully acknowledged. Human TSH for iodination was provided by the National Pituitary Agency and Endocrinology Study Section of the National Institute of Arthritis and Metabolic Disease, human TSH as standard A was supplied by Dr. R. Bangham, of the National Institute for Medical Research, and human TSH for immunization purposes was provided by Dr. A. Hartree.

\section{References}

Adams, D. D., Kennedy, T. H., and Utiger, R. D. (1970). Abstracts of the Sixth International Thyroid Conference, Vienna

Adams, L., and Maloof, F. (1970). Fournal of Clinical Investigation, 49, 1a. Bowers, C. Y., et al. (1970). Biochemical and Biophysical Research Communications, 39, 352

Doniach, I. (1960). British Medical Bulletin, 16, 99.

Fisher, D. A., and Odell, W. D. (1969). Journal of Clinical Investigation, 48,1670 .

Fleischer, N., Burgus, R., Vale, W., Dunn, T., and Guillemin, R. (1970). Fournal of Clinical Endocrinology and Metabolism, 31, 109

Greer M. A and DeGroot, L. J. (1956). Metabolism, 5, 682.

Hall, R., and Amos, J. (1971). In Radioimmunoassay Methods, ed. K. E. Kirkham and W. M. Hunter. To be published.

Hall, R. Tubmen, J., and Garry, R. (1970a). Clinical Science, 38, 18P

Hall, R., Amos, J., Garry, R., and Buxton, R. L. (1970b). British Medical fournal, 2, 274.
Hamilton, C. I., Adams, L. C., and Maloof, F. (1970). New England Fournal of Medicine, 283, 1077.

Hunter, W. M., and Greenwood, F. C. (1962). Nature, 194, 495.

Kirkham, K. E., Hunter, W. M., Jeffery, F. H., and Bennie, J. G. (1970) In In Vitro Procedures with Radioisotopes in Medicine. Vienna, International Atomic Energy Agency.

Lemarchand Béraud, Th., Griessen, M., and Scazziga, B. R. (1970). Abstracts of the Sixth International Thyroid Conference, Vienna.

Lemarchand Béraud, Th., and Vanotti, A. (1965). In Current Topics in Thyroid Research, ed. C. Cassano and M. Andreoli, p. 527. New York, Academic Press.

Mercer, C. J., Sharard, A., Westerink, C. J. M., and Adams, D. D. (1960). Lancet, $2,19$.

Nicoloff, J. T., Gross, H. A., and Appleman, D. (1970). Abstracts of the Sixth International Thyroid Conference, Vienna.

Odell, W. D., Wilber, J. F., and Paul, W. E. (1965). Fournal of Clinical Endocrinology and Metabolism, 25, 1179.

Odell, W. D., Utiger, R. D., and Wilber, J. F. (1967). Recent Progress in Hormone Research, 23, 47 .

Odell, W. D., Vanslager, D. L., and Bates, R. (1968). In Radioisotopes in Medicine: In Vitro Studies, ed. R. L. Hayes, F. A. Goswitz, and B. E. P. Murphy, p. 185. Oak Ridge, Tennessee, U.S. Atomic Energy Commission

Raud, H. R., and Odell, W. D. (1969). British Fournal of Hospital Medicine,

2, 1366.
Rodbard, D., Rayford, P. L., Cooper, J. A., and Ross, G. T. (1968). fournal of Clinical Endocrinology and Metabolism, 28, 1412 .

Sawin, C. T., Hershman, J. M., Handler, S. D., and Utiger, R. D. (1970) Metabolism, 19, 488.

Utiger, R. D. (1965). Fournal of Clinical Investigation, 44, 1277.

Wayne, E. J., Koutras, D. A., and Alexander, W. D. (1964). Clinical Aspects of Iodine Metabolism, p. 102. Oxford, Blackwell Scientific.

Webster, B. R., and Greenwood, F. C. (1968). In Protein and Polypeptide Hormones, ed. M. Margoulies, p. 32. Amsterdam, Excerpta Medica Foundation.

Wilber, J. F., and Baum, D. (1970). Journac of Clinical Endocrinology and Metabolism, 31, 372

Yalow, R. S., and Berson, S. A. (1966). Nature, 212, 357.

\title{
Diazepam and Tests of Thyroid Function
}

\author{
FREDERICK CLARK, REGINALD HALL， BRIAN J. ORMSTON
}

British Medical fournal, 1971, 1, 585-586

\section{Summary}

The effect of diazepam on thyroid function tests was examined in 12 euthyroid patients requiring the drug for psychiatric reasons and in six patients with thyrotoxicosis. Assessment was made before and after four weeks' therapy.

There was no significant difference in results from tests of thyroid iodide trapping and binding (thyroid radioiodine uptake, thyroid clearance, and absolute iodine uptake) except in the one-hour thyroid uptake in the euthyroid group, which was increased after diazepam. This increase occurred without alteration in serum thyroid stimulating hormone levels. No change occurred in either group in tests of thyroid hormone release (protein-bound iodine, T-3 resin uptake, or Thyopac-3 and free thyroxine index).

Patients with suspected thyroid disease who are taking diazepam do not need to stop therapy while their thyroid status is being determined.

Newcastle General Hospital, Newcastle upon Tyne NE4 6BE FREDERICK CLARK, M.B., M.R.C.P., Consultant Physician, and Lecturer in Clinical Medicine, University of Newcastle upon Tyne

\section{Royal Victoria Infirmary, Newcastle upon Tyne NE1 4LP}

REGINALD HALL, M.D., F.R.C.P., Consultant Physician, and Professor of Medicine, University of Newcastle upon Tyne

BRIAN J. ORMSTON, M.B., B.S., Research Fellow in Medicine

\section{Introduction}

Since the report that diazepam (Valium) caused depression of thyroid uptake of ${ }^{131}$ I (Harvey, 1967), statements have appeared in the literature which tend to perpetuate this belief (Today's Drugs, 1969; Walton and Thompson, 1969; Year Book of Drug Therapy, 1970). Earlier, Schindler et al. (1966) had failed to show any effect of the drug on pituitary thyroid stimulating hormone (TSH) release or thyroid gland activity in the mouse, and in a double-blind placebo controlled study in normal volunteers Mazzaferri and Skillman (1969) were unable to substantiate any change in thyroid function after diazepam. Likewise, Greenberg et al. (1970) could find no effect on laboratory measurements of thyroid function in three patients with thyrotoxicosis. In in-vitro experiments interference by diazepam with the estimation of protein-bound iodine (P.B.I.) which led to falsely raised values has been noted (Tegeris $e t$ al., 1969). The concentration of diazepam used, however, was considerably higher than would be expected in clinical usage.

In view of these conflicting reports, and as diazepam is a commonly prescribed drug, it was considered that additional examination was necessary to ascertain the effect, if any, of the agent on commonly used tests of thyroid function in cuthyroid and thyrotoxic individuals.

\section{Subjects and Methods}

These were similar to those used for chlordiazepoxide (Clark and Hall, 1970). Twelve euthyroid patients (11 women and 1 man, aged 29 to 54 years) and six patients with thyrotoxicosis (all women, aged 28 to 49) were tested before and after four iveeks of therapy with diazepam $5 \mathrm{mg}$ three times a day. The 
TABLE I-Thyroid Function Tests in Euthyroid Patients before and during Treatment with Diazepam*

\begin{tabular}{|c|c|c|c|c|c|c|c|c|c|c|c|c|c|c|}
\hline & & \multicolumn{4}{|c|}{$\because{ }^{13} 1$ I Thyroid Uptake } & \multirow{2}{*}{$\begin{array}{l}\text { Thyroid } \\
\text { Clearance } \\
(\mathrm{ml} / \mathrm{min})\end{array}$} & \multirow{2}{*}{$\begin{array}{c}\text { Renal } \\
\text { Clearance } \\
\text { (ml/min) }\end{array}$} & \multirow{2}{*}{$\begin{array}{c}\text { Urinary } \\
\text { Inorganic } \\
\text { Iodide } \\
(\mu \mathbf{g} / 100 \mathrm{ml})\end{array}$} & \multirow{2}{*}{$\begin{array}{c}\text { Plasma } \\
\text { Inorganic } \\
\text { Iodide } \\
(\mu \mathrm{g} / 100 \mathrm{ml})\end{array}$} & \multirow{2}{*}{$\begin{array}{l}\text { Absolute } \\
\text { Iodine } \\
\text { Uptake } \\
(\mu \mathrm{g} / \mathrm{hr})\end{array}$} & \multirow{2}{*}{$(\mu \mathrm{g} \cdot 100 \mathrm{ml})$} & \multirow{2}{*}{$\begin{array}{c}\mathrm{T}_{3} \text { Resin } \\
\text { Uptake } \\
\text { Ratio }\end{array}$} & \multirow{2}{*}{$\begin{array}{c}\text { Free } \\
\text { Thyroxine } \\
\text { Index }\end{array}$} & \multirow{2}{*}{$\underset{(\mu \mathrm{U} / \mathrm{ml})}{\mathrm{TSH}}$} \\
\hline & & $1 \mathrm{hr}$ & $2 \frac{1}{2} \mathrm{hr}$ & $6 \mathrm{hr}$ & $24 \mathrm{hr}$ & & & & & & & & & \\
\hline No. of subjects & . & 10 & 10 & 7 & 8 & 9 & 8 & 7 & 7 & 7 & 11 & 11 & 11 & 6 \\
\hline $\begin{array}{l}\text { Before treatment: } \\
\text { Mean } \\
\text { S.D. . } \\
\text { During treatment: }\end{array}$ & $\begin{array}{l}\cdots \\
\cdots\end{array}$ & $\begin{array}{l}8.95 \\
2.98\end{array}$ & $\begin{array}{r}15 \cdot 68 \\
5 \cdot 71\end{array}$ & $\begin{array}{l}26 \cdot 53 \\
12 \cdot 17\end{array}$ & $\begin{array}{l}36 \cdot 88 \\
12 \cdot 12\end{array}$ & $\begin{array}{l}18 \cdot 28 \\
10 \cdot 01\end{array}$ & $\begin{array}{r}31.38 \\
6.75\end{array}$ & $\begin{array}{l}4 \cdot 76 \\
3 \cdot 22\end{array}$ & $\begin{array}{l}0.20 \\
0.07\end{array}$ & $\begin{array}{l}1.80 \\
1.04\end{array}$ & $\begin{array}{l}6 \cdot 76 \\
1 \cdot 30\end{array}$ & $\begin{array}{l}0.93 \\
0.12\end{array}$ & $\begin{array}{l}6 \cdot 17 \\
0.88\end{array}$ & $\begin{array}{l}2.35 \\
1.01\end{array}$ \\
\hline $\begin{array}{ll}\text { Mean } & \cdots \\
\text { S.D. . } & \cdots\end{array}$ & $\begin{array}{l}\cdots \\
\cdots\end{array}$ & $\begin{array}{r}10.51 \\
3.95\end{array}$ & $\begin{array}{r}17 \cdot 52 \\
6 \cdot 26\end{array}$ & $\begin{array}{l}29 \cdot 20 \\
14 \cdot 84\end{array}$ & $\begin{array}{l}39 \cdot 38 \\
10 \cdot 31\end{array}$ & $\begin{array}{r}21 \cdot 17 \\
9 \cdot 59\end{array}$ & $\begin{array}{r}31.71 \\
4.62\end{array}$ & $\begin{array}{l}3 \cdot 01 \\
1 \cdot 74\end{array}$ & $\begin{array}{l}0.21 \\
0.08\end{array}$ & $\begin{array}{l}2 \cdot 18 \\
1 \cdot 01\end{array}$ & $\begin{array}{l}7 \cdot 18 \\
1 \cdot 37\end{array}$ & $\begin{array}{l}0.92 \\
0 \cdot 10\end{array}$ & $\begin{array}{l}6 \cdot 49 \\
0.90\end{array}$ & $\begin{array}{l}2 \cdot 23 \\
0 \cdot 76\end{array}$ \\
\hline $\begin{array}{l}\text { Mean of individual } \\
\text { differences } \ldots\end{array}$ & . & +1.56 & $+1 \cdot 84$ & $+2 \cdot 67$ & $+2 \cdot 50$ & $+2 \cdot 89$ & +0.33 & $-1 \cdot 75$ & +0.01 & +0.38 & +0.42 & -0.01 & +0.32 & -0.12 \\
\hline $\begin{array}{c}\text { S.E. of mean } \\
\text { difference }\end{array}$ & . & 0.85 & $1 \cdot 34$ & $3 \cdot 28$ & $2 \cdot 20$ & $2 \cdot 03$ & 1.73 & 0.94 & 0.04 & 0.49 & 0.27 & 0.02 & 0.21 & 0.37 \\
\hline . & . & 0.05 & N.S. & N.S. & N.S. & N.S. & N.S. & N.S. & N.S. & N.S. & N.S. & N.S. & N.S. & N.S. \\
\hline
\end{tabular}

N.S. = Not significant.
*The statistical tests are based on within-patient comparisons.

TABLE II-Thyroid Function Tests in Thyrotoxic Patients before and during Treatment with Diazepam*

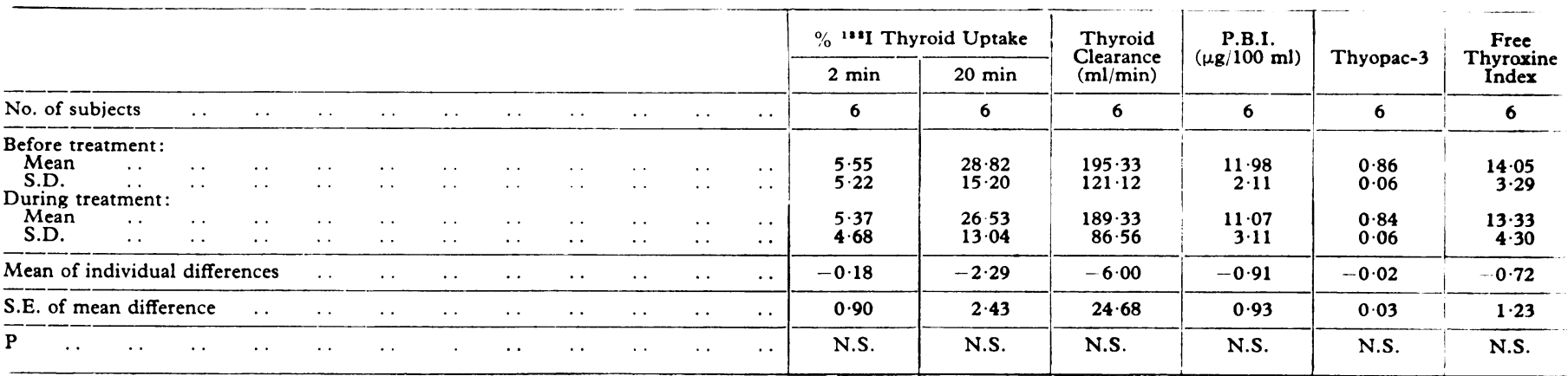

*The statistical tests are based on within-patient comparisons.

tests differed in the thyrotoxic group from those in the chlordiazepoxide trial in that Thyopac-3 (Radiochemical Centre, 1969; Clark and Brown, 1970a) replaced the T-3 resin uptake and the free thyroxine index was derived from P.B.I. and Thyopac-3 (Clark and Brown, 1970b). In the euthyroid group the level of thyroid-stimulating hormone (TSH) in serum was also determined (Hall et al., 1971) (normal range 0.6-4.2 $\mu \mathrm{U} / \mathrm{ml})$.

\section{Results}

The results obtained in the euthyroid group are shown in Table I. There was a small but significant increase (at the $5 \%$ level) in the one-hour thyroid uptake of ${ }^{131}$ I after diazepam but not in any other measurement. The results in the thyrotoxic group are shown in Table II. No significant change occurred in any value after diazepam.

\section{Discussion}

The findings in the euthyroid group are by and large similar to those of Mazzaferri and Skillman (1969), who were unable to show any change in P.B.I., thyroxine level, T-3 resin uptake, and 24-hour thyroid uptake of ${ }^{131} I$ which could be attributed solely to diazepam. Our more detailed thyroid uptake studies, however, have shown a small but significantly increased uptake at one hour after treatment with diazepam. The meaning of this increase is obscure. There was no difference in TSH levels measured before and after administration of the drug. The change, if real, is minimal and can prebably be ignored, particularly as there is no significant alteration in the more commonly used six-hour and 24-hour uptake values.

In the thyrotoxic series the results agree with those of Greenberg et al. (1970), who showed that diazepam did not alter laboratory test indices. They do not confirm the report by Harvey (1967) of depression of thyroid uptake.

It is concluded that diazepam need not be withdrawn before radioisotope or biochemical evaluation of a patient with suspected thyroid disease is undertaken.

We wish to thank Dr. H. Folgate, of Roche Products Ltd., Professor F. T. Farmer, Professor G. A. Smart, and Professor D. J. Newell, of the University of Newcastle upon Tyne, for advice and help; members of the Prospect House Medical Group, Newcastle upon Tyne, for referring the euthyroid patients; and Mrs. M. A. Beck and Mrs. E. M. Burleigh for technical help.

\section{References}

Clark, F., and Brown, H. J. (1970a). British Medical fournal, 1, 713.

Clark, F., and Brown, H. J. (1970b). British Medical łournal, 2, 543, 672. Clark, F., and Hall, R. (1970). British Medical Yournal, 2, 266.

Greenberg, A. H., Czernichow, P., and Blizzard, R. M. (1970). fohn Hopkins Medical Fournal, 126, 134.

Hall, R., Amos, J., and Ormston, B. J. (1971). British Medical fournal, 1, 582. Harvey, R. F. (1967). British Medical fournal, 2, 52.

Mazzaferri, E. L., and Skillman, T. G. (1969). American Fournal of the Medical Sciences, 257, 388.

Radiochemical Centre, Amersham (1969). Technical Bulletin 69/7 on Thyopac-3.

Schindler, W. J., Matthews, M. G., and McHorse, T. S. (1966). Federation Proceedings, 25, 380

Tegeris, A. S., Cottrell, J. C., and Cruz, E. A. (1969). Toxicology and Applied Pharmacology, 14, 618.

Today's Drugs (Thyroid Hormones) (1969). British Medical fournal, 2, 561. Walton, J. G., and Thompson, J. W. (1969). British Dental fournal, 127, 379. Year Book of Drug Therapy (1970). Editor D. G. Friend, p. 398. Chicago, Year Book Medical Publishers. 